\title{
RESPONSE OF JAPANESE QUAIL TO FEED BY ORGANIC COMPOUNDS
}

\author{
M.A.A. Abdel-Mageed and E.M. EL-Kamash
}

Animal Prod. Res. Inst., Agric. Res. Center, Ministry of Agric, Doki, Giza, Egypt.

\section{ABSTRACT:}

The experiment was carried out at the Poultry Farm, Faculty of Agriculture, Fayoum University (middle Egypt). This study aims to show the effect of dietary malic acid (MA) supplementation as a growth promoter on Japanese quail performance, carcass characteristics, intestinal villi and $\mathrm{pH}$, bacteria enumeration, some blood parameters and digestibility coefficients. A total number of 360 unsexed one day-old Japanese quail chicks (Coturnix coturnix japonica) were equally divided into four groups of six replicates each. Two starter-grower corn-soybean meal (C-SBM) basal diets were formulated to contain $24 \% \mathrm{CP}$ and $2900 \mathrm{kcal} \mathrm{ME} / \mathrm{kg}$ diet and $22 \% \mathrm{CP}$ and $2750 \mathrm{kcal} \mathrm{ME} / \mathrm{kg}$ diet, respectively. Also, two layer C-SBM basal diets were formulated to contain $20 \% \mathrm{CP}$ and $2900 \mathrm{kcal} \mathrm{ME} / \mathrm{kg}$ diet and $18 \% \mathrm{CP}$ and $2750 \mathrm{kcal}$ $\mathrm{ME} / \mathrm{kg}$ diet, respectively. Each of the four basal diets was either unsupplemented or supplemented with $0.15 \%(1.5 \mathrm{~kg} /$ ton$)$ dietary malic acid. Therefore, four experimental treatments were used in both startinggrowing and laying periods. Each chick group fed one of the four experimental diets. At 35 days of age, a slaughter test was performed to determine carcass traits, edible giblets, lymphoid organs and intestinal villi, microflora count and $\mathrm{pH}$. Blood samples were taken and assayed to determine some serum blood parameters. Digestibility trials were conducted to determine nutrients digestibility for starter-grower experimental diets. At laying period, egg number, weight, mass and production rate as well as feed intake and feed conversion were recorded. At the end of the 90-day period, egg samples were taken and broken out to determine internal egg quality and analysis. From nutritional of view, it was observed that using malic acid at a level of $0.15 \%(1.5 \mathrm{~kg} / \mathrm{ton})$ in Japanese quail diets containing sub-optimal energy and protein levels helped in reducing microflara count, particularly pathogens and in turn, improved quail performance and immunity. However, using MA at a level of $0.15 \%(1.5 \mathrm{~kg} / \mathrm{ton})$ in Japanese quail diets containing optimal energy and protein levels caused an increase in egg mass and a decrease in feed intake.

Key words: Malic acid, growth performance, carcass, villus height and width, bacteria enumeration and intestinal $\mathrm{pH}$, blood serum, egg production, digestibility trials, egg quality, quail.

Fayoum J. Agric. Res. \& Dev., Vol. 31, No.2, July, 2017 

INTRODUCTION

Antibiotic growth promoters (AGP) in poultry diets have been banned for use due to the possibilities of antibiotic residue, the development of drugresistant bacteria and a reduction in the ability to cure these bacterial diseases in humans (Jensen, 1998). Patten and Waldroup (1988) reported that supplementing poultry diets with organic acids has become an important nutritional strategy to improve performance and health status of poultry fed diets devoid of AGP. Organic acids, as feed additives have received increasing attention as alternative AGP. It has made a tremendous contribution to the profitability in the intensive husbandry and providing people with healthy and nutritious poultry products. Livestock performance and feed efficiency are closely related with qualitative and quantitative microbial load of host animal including load in alimentary tract and environment (Garrido et al., 2004). Malic acid (MA) is formed in metabolic cycles in the cells of plants and animals, including chickens and plays an important role in generating mitochondrial ATP both under aerobic and hypoxic conditions. Malic acid is not antibiotics but, if used correctly along with nutritional, managerial and biosecurity measures, it can be a powerful tool in maintaining the health of the gastrointestinal tract of poultry, thus improving their zootechnical performances (Moharrery and Mahzonieh, 2005). Therefore, searching for alternative products that can be used in poultry feeds and aid in growth promotion, feed utilization improvement, and maintenance of gut health are taking place. Organic acids may stimulate endogenous enzymes, regulate gut microbial flora and help in maintaining animal's health. The key basic principle on the mode of action of organic acids on bacteria is that nondissociated (non-ionised, more lipophilic) organic acids can penetrate the bacteria cell wall and disrupt the normal physiology of certain types of bacteria (Dhawale, 2005).

Malic acid (MA), an alpha-hydroxy organic acid, is a colorless, crystalline compound, $\mathrm{COOH} \cdot \mathrm{CH} 2 \cdot \mathrm{CHOH} \cdot \mathrm{COOH}$, that occurs naturally in a wide variety of unripe fruit, including apples. It is sometimes referred to as a fruit acid. It is also formed in metabolic cycles in plant and animal cells, including chickens. Peripheral malate derives from feed sources and from synthesis in citric acid or Krebs cycle located in cells' mitochondria (Lehninger, 1978 and Van Kol, 2005). Literature on dietary MA effect in poultry is limited and the evidence by which exogenous MA may affect quail performance is also limited. Therefore, the purpose of the current study was to evaluate the effects of dietary MA supplementation on Japanese quail performance, carcass characteristics, intestinal villi and $\mathrm{pH}$, bacteria enumeration.

\section{MATERIALS AND METHODS}

The experiment was carried out at the Poultry Farm, Faculty of Agriculture, Fayoum University (middle Egypt). Three hundred and sixty

Fayoum J. Agric. Res. \& Dev., Vol. 31, No.2, July, 2017 
RESPONSE OF JAPANESE QUAIL TO FEED BY ORGANIC

unsexed one day-old Japanese quail chicks were used in a 35 day growing trial. Chicks were individually wing-banded, weighed, and randomly distributed into four experimental groups of similar mean body weight $(7.82 \pm 0.07 \mathrm{~g} / \mathrm{bird})$ of 90 birds each, which consists of six replicates of 15 birds each. At 35 days of age, birds were transferred to layer quail cages for a 90-day laying trial.

\section{Management and experimental diets}

Quail chicks were reared under similar management conditions. Ambient temperature was maintained at $34-36^{\circ} \mathrm{C}$ during the 1 st week and weekly decreased by $2^{\circ} \mathrm{C}$ for the next three weeks. During the 5 th and 6 th week, temperature was maintained at $20-22^{\circ} \mathrm{C}$. Birds daily received continuous artificial lighting during growing trial and $17 \mathrm{~h}$ afterwards. Chicks were fed the starter-grower diets from one to 35 day and the layer diets from 35 to 125 day of age. Mash feed and clean fresh tap water were provided ad liblitum.

Two starter-grower corn-soybean meal (C-SBM) basal diets were formulated, from the same batches of components, to contain $24 \% \mathrm{CP}$ and $2900 \mathrm{kcal} \mathrm{ME}$ $/ \mathrm{kg}$ diet (HPHE-diet) and $22 \% \mathrm{CP}$ and $2750 \mathrm{kcal} \mathrm{ME} / \mathrm{kg}$ diet (LPLE-diet). Also, two layer C-SBM diets were formulated to contain $20 \% \mathrm{CP}$ and 2900 $\mathrm{kcal} \mathrm{ME} / \mathrm{kg}$ diet and $18 \% \mathrm{CP}$ and $2750 \mathrm{kcal} \mathrm{ME} / \mathrm{kg}$ diet. Each of the 4 basal diets was either unsupplemented or supplemented with $0.15 \%(1.5 \mathrm{~kg} / \mathrm{ton}) \mathrm{MA}$. Therefore, four experimental treatments were used in both starting-growing and laying periods. Each chick group was fed one of the four experimental diets. The composition and calculated analysis of the experimental diets are shown in Table (1).

\section{Measurements and collected data}

\section{Growth performance}

Individual body weight ( $\mathrm{g}$ ) and feed intake (FI, g/bird) were weekly recorded to determine body weight gain $(\mathrm{g}$ ), feed conversion ratio ( $\mathrm{g}$ feed/g gain), protein conversion ratio and caloric conversion ratio. Mortality rate $\%$ was also calculated on a weekly basis.

\section{Carcass parameters}

At the end of the starting-growing period (35 days), 48 birds (six $\hat{\sigma}+$ six $9 /$ treatment) used to determine carcass characteristics. BW nearly close to the mean were slaughtered to obtained the following criteria eviscerated carcass, dressing, breast and thigh weights. Abdominal fat was removed from gizzard and abdominal region and individually weighed for each carcass. Ovary-oviduct was carefully separated and accurately weighed. Edible giblets (liver, heart and gizzard) were individually separated and weighed. Lymphoid organs (thymus, bursa and spleen) were individually removed, weighed and calculated for each organ as \% of live BW.

\section{Villus height and width}

Digesta from gastrointestinal tract were flushed at $\mathrm{pH} 7.4$ to avoid damaging tissues. Intestinal samples of one $\mathrm{cm}$ in length were taken from the

Fayoum J. Agric. Res. \& Dev., Vol. 31, No.2, July, 2017 
middle of each segment of the duodenum, jejunum, and ileum. Samples were then fixed in $10 \%$ buffered neutral formaldehyde solution, processed, and cut to $6-\mu \mathrm{m}$ sections that were stained with hematoxylin and eosin and examined with a light microscope. A digital camera was used and villus height was measured from tip to villus bottom. Villus width was measured at villi bottom.

\section{Bacteria enumeration and intestinal $\mathbf{p H}$}

At slaughter test performed using three samples of ileum content for each treatment were taken. Total microflora, colibacillus and lactobacillus of ileum content were enumerated. Lactobacilli/colibacillus ratio was also calculated. The $\mathrm{pH}$ of intestinal contents was directly determined by $\mathrm{pH}-$ meter.

\section{Blood serum parameters}

At the time of slaughter test, 48 blood samples (six $\delta$ and six $q$ / treatment) were taken and serum was separated by centrifugation for 10 minutes $(3000 \mathrm{rpm})$ and stored in vials at $-20^{\circ} \mathrm{C}$ for later analysis. Frozen serum was thawed and assayed to determine, on individual bases, some biochemical parameters by using suitable commercial diagnostic kits and Atomic Absorption Spectrophotometer, following the same steps as described by manufactures. Colorimetric determination of serum total protein (TP, g/100 $\mathrm{ml}$ ) was measured according to Henry (1974). Albumin concentration (Alb, $\mathrm{g} / 100 \mathrm{ml}$ ) was determined. Globulin concentration (Glo, g/100 ml) was calculated by the difference between $\mathrm{TP}$ and $\mathrm{Alb}$, since the fibrinogen usually comprises a negligible fraction (Sturkie, 1986). The Alb/Glo ratio was also calculated. Total lipids (TL, g/100 ml) and cholesterol (Cho, mg/100ml) were also determined.

\section{Digestibility trials}

A total number of 24 adult $\delta$ quail of six-weeks old were selected at the end of the growing trial and individually housed in metabolic cages for carrying out four digestibility trials ( $\mathrm{six} \hat{\sigma} /$ treatment) to determine the nutrient digestibility coefficient for dietary treatments in terms of crude protein $(\mathrm{CP})$, crude fiber (CF), ether extract (EE) and nitrogen free extract (NFE) values. Digestibility trials lasted for seven days, a four-day preliminary period for adaptation to metabolic cages followed by a three-day main collection period in which FI was offered on an ad libitum daily basis and excreta output was quantitatively collected for each $\delta$ over three consecutive days.

\section{Egg traits and quality}

Eggs were daily collected and weighed. Averages of egg number (EN), egg weight (EW), egg mass (EM) and feed conversion ratio (FCR) were weekly calculated per each replicate for a 90-day laying period. Egg quality was assessed on five eggs collected per replicate during three days at the end of the 90-day period. Egg shape index (ESI) was determined according to Stadleman (1977). Eggs were broken out and the liquid contents were put a side and shell plus membranes washed to remove adhering albumen. After drying, shell

Fayoum J. Agric. Res. \& Dev., Vol. 31, No.2, July, 2017 
RESPONSE OF JAPANESE QUAIL TO FEED BY ORGANIC

weight \% was measured. Shell thickness (STh) was measured by using a micrometer as an average of three points (top, medial and base). Egg analysis including albumin protein $\%$, yolk protein $\%$, ether extract $\%$ and cholesterol (mg /gm yolk) were performed according to Washburn and Nix (1974).

Chemical and statistical analysis

Experimental diets and excreta were analyzed following procedures detailed by the Association of Official Analytical Chemists (AOAC 1990) for $\mathrm{CP}, \mathrm{CF}, \mathrm{DM}$ and EE. The NFE was calculated by the difference. Metabolizable energy (ME) of experimental diets was calculated considering the ME values of different feed ingredients (NRC, 1994). Fecal nitrogen was determined according to Jakobsen et al. (1960).

Obtained data were expressed as means \pm standard error and statistically analyzed by analysis of variance (ANOVA) as a factorial arrangement of $2 \times 2$ according to Steel and Torrie (1980). Also, the General Linear Model (GLM) procedure of SPSS (1993) computer statistical program was used. The significant means were ranked using Duncan's Range Test (Duncan, 1955). Statistical significance level was tested at probability of $\mathrm{P} \leq 0.05$.

\section{RESULTS AND DISCUSSION}

\section{Growth performance}

The results presented in Table (2) show the mean values of growth performance parameters in terms of body weight (BW), feed intake (FI), body weight gain (BWG), feed conversion ratio (FCR), protein conversion ratio, (PCR), caloric conversion ratio (CCR) and mortality rate (MR) \%. Apart from MA, it was observed that feeding HPHE-diets resulted in significant increase in BW, BWG, FI, PI, CI, PCR and CCR values and significant decrease in MR \% as compared to LPLE-diets. However, FCR was not significantly affected. Aside from diet type, feeding MA-supplemented diets gave significant improvement in BW, BWG, FCR, PCR and CCR as well as significant decrease in FI and MR \% in comparison to MA-free diets. However, both PI and CI were not significantly affected. Supplementing MA to HPHE-diet had no significant effect on BW, BWG, FCR, PI, CI, PCR and CCR, whereas it significantly decreased FI and MR \% as compared to the corresponding control diet. However, supplementing MA to LPLE-diet significantly improved BW, BWG, FCR, PCR and CCR significantly decreased FI and MR \%, but it had no significant effect on PI and CI.

These results are in agreement with those showed that organic acids have positive effects on poultry growth (Chaveerach et al., 2004) and FI was decreased with increasing dietary propionic acid levels (Cave, 1984). The improvement in FC may be due to the acidic conditions that make the nutrients more available (Boling et al., 2001) which monitors better performance. Oppositely, other results have shown that adding MA in drinking water did not show significant difference in BW (Moharrery and Mahzonieh, 2005) and

Fayoum J. Agric. Res. \& Dev., Vol. 31, No.2, July, 2017 
BW was not significantly affected by organic acid treatments (Denli et al., 2003).

\section{Carcass characteristics}

Information found in Table (3) indicate that birds given HPHE-diet had significantly higher eviscerated carcass $\%$, dressing $\%$, breast $\%$ and ovaryoviduct $\%$ but significantly decreased abdominal fat $\%$ as compared to those fed LPLE-diet regardless of MA. Irrespective of diet type, no significant influence was found due to MA supplementation on carcass parameters except for abdominal fat $\%$ that was significantly decreased and ovary-oviduct $\%$ that was significantly increased. Adding MA to HPHE-diet had no significant influence on eviscerated carcass $\%$, dressing $\%$, breast $\%$, abdominal fat $\%$ and ovaryoviduct $\%$ as compared to the corresponding MA- free diet. However, supplementing MA to LPLE-diet had significantly increased eviscerated carcass $\%$, dressing $\%$, breast $\%$ and ovary-oviduct $\%$. However, abdominal fat $\%$ was significantly decreased as compared to the corresponding MA- free diet.

\section{Edible giblets and lymphoid organs}

Data in Table (4) indicated that regardless of MA, feeding HPHE-diet had significantly higher liver $\%$ and heart $\%$. However, gizzard \% was not significantly affected as compared to LPLE-diet. Regardless of diet type, MA supplementation caused no significant effect on edible giblets. Supplementing MA to HPHE- or LPLE-diets had no effect on edible giblets as compared to the corresponding MA-free diet. Concerning lymphoid organs results, it was noticed that neither diet type nor MA showed significant effect, except for thymus gland that was significantly increased by MA supplementation. Adding MA to HPHE- or LPLE-diets caused a significant increase in lymphoid organs $\%$ as compared to the corresponding MA-free diet.

The present results are in agreement with those have shown that liver \% was not significantly affected by MA (Moharrery and Mahzonieh, 2005) and organic acids (Denli et al. 2003). It can be seem that thymus is a good indicator of immune function. Shelat et al. (1997) revealed that thymus size is a sensitive indicator of health and acute or chronic stress response.

Villus height and width

The mean values of intestinal villus height and width are summarized in Table (5). Apart from MA, diet type caused no significant effect on villus height and width in different intestinal segments. Irrespective of diet type, MA supplemented-diets had significantly increased intestinal villus height and width in different intestinal segments as compared to MA-free diets. Supplementing MA to HPHE- or LPLE-diets had significantly increased intestinal villus height and width in different intestinal segments as compared to the corresponding MA-free diets.

Fayoum J. Agric. Res. \& Dev., Vol. 31, No.2, July, 2017 
RESPONSE OF JAPANESE QUAIL TO FEED BY ORGANIC 177 Bacteria enumeration and intestinal $\mathbf{p H}$

The mean values of total microflora count, lactobacillus, colibacillus and lactobacillus/colibacillus ratio of the ileum content as well as intestinal $\mathrm{pH}$ are given in Table (6). Regardless of MA, diet type caused no significant effect on total microflora count, colibacillus and lactobacillus and lactobacillus/colibacillus ratio of the ileum content as well as intestinal $\mathrm{pH}$. Irrespective of diet type, MA supplementation resulted in significant decrease in total microflora count, colibacillus count and intestinal $\mathrm{pH}$ as well as significant increase in lactobacillus count, lactobacillus/colibacillus ratio as compared to MA-free diets. Supplementing MA to HPHE- or LPLE-diets resulted in significant decrease in total microflora count, colibacillus count and intestinal $\mathrm{pH}$ as well as significant increase in lactobacillus count, lactobacillus/colibacillus ratio as compared to the corresponding MA-free diets.

These results are in agreement with those of Moharrery and Mahzonieh, (2005) who found that E. coli count was significantly decreased by MA. This was due to organic acids that can inhibit growth of many bacteria and toxin-producing molds (Roy, 2002). Intestinal $\mathrm{pH}$ was not affected by formic and propionic acids (Thompson and Hinton, 1997). The acidic pH allows establishment of microorganisms, particularly Lactobacillus spp. (Sarra et al., 1985) and prevents $E$. coli growth and these conditions make the absorptive area more beneficial (Dofing and Gottschal, 1997).

Blood serum parameters

Results concerning total protein (TP), albumin (Alb), globulin (Glo), Alb/Glo ratio, total lipids (TL) and cholesterol (Cho) are shown in Table (7). There were no significant differences in either TP or Cho among different treatments. Irrespective of MA, HPHE-diet caused significant increase in Alb and Alb/Glo ratio and significant decrease in Glo and TL. Regardless of diet type, MA supplementation resulted in no significant differences among all studied traits. Supplementing MA to HPHE-diet had similar Alb, Glo, Alb/Glo ratio and TL values to those of the corresponding MA-free diet. The same trend was observed in case of supplementing MA to LPLE-diet.

Nutrients digestibility coefficients

Data regarding digestibility coefficients of crude protein (CP), crude fiber (CF), ether extract (EE) and nitrogen free extract (NFE) values for experimental starter-grower diets are given in Table (8). There were no significant differences in CF and NFE digestibilities among different treatments. Apart from MA, HPHE-diet caused significant increase in $\mathrm{CP}$ and EE digestibility as compared to LPLE-diet. Away from diet type, MA supplementation caused significant increase for only $\mathrm{CP}$ digestibility. Supplementing MA to HPHE-diet had similar CP and EE digestibility as compared to the corresponding MA-free diet. However, supplementing MA to LPLE-diet caused a significant increase in CP and similar EE digestibility as

Fayoum J. Agric. Res. \& Dev., Vol. 31, No.2, July, 2017 
compared to the corresponding MA-free diet In general, the improvement due to adding MA may be attributed to improving intestinal microbial balance. In other words, MA helps to keep the intestinal tract healthy and when the epithelial tissue is healthy, there is improve and better absorption of all nutrients (Kaistha et al., 1996).

\section{Egg analysis}

Results concerning egg analysis in terms of albumin protein (Albp) \%, yolk protein (Yp) \%, yolk ether extract (YEE) \% and yolk cholesterol (YCho) are shown in Table (9). Regardless of MA, HPHE-diet caused significant increase in Yp \% and significant decrease in YEE \% and YCho \%. These results are in agreement with previous studies of Andersson (1979); Akbar et al. (1983) and Garcia et al. (2005) who reported that Yp contents increased with higher dietary CP levels. Irrespective of diet type, MA supplementation caused significant decrease in YCho \%. Supplementing MA to HPHE-diet caused similar Yp \% and YEE \% as well as significant decrease in YCho \% as compared to the corresponding MA-free diet. The same trend was observed in case of supplementing MA to LPLE-diet.

\section{Egg quality}

Data regarding egg quality in terms of shell thickness (STh), egg shape index (ESI), egg specific gravity (ESG), albumin weight (Alb) \%, shell weight (S) $\%$ and yolk weight (Y) $\%$ are presented in Table (10). There were no significant differences in SG, Y \% and Alb \% among different treatments. These results are in a relative harmony with the results of Garcia et al. (2005) who reported that dietary $\mathrm{CP}$ levels had no effect on $\mathrm{Y} \%$. On the contrary, increasing CP level increased Y \% and reduced Alb \% (Akbar et al., 1983), increased $Y \%$ (Yakout et al., 2004) and decreased Y \% (Zanaty, 2006). Regardless of MA, HPHE-diet caused significant increase in STh, ESI and S \%. Similar observations have been reported by Yakout et al. (2004) and Zanaty (2006) who found that STh was significantly increased with increasing CP. This may be due to the increase in EW or the enhancing of Ca deposition in the shell matrix. Irrespective of diet type, MA supplementation caused significant increase in STh, ESI and S \%. Supplementing MA to HPHE-diet had similar ESI, STh and S \% to those of the corresponding MA-free diet. However, supplementing MA to LPLE-diet caused significant increase in ESI, STh and S $\%$ as compared to the corresponding MA-free diet. Laying performance

Results concerning laying performance in terms of egg production (EP) $\%$, egg number (EN), egg weight (EW), egg mass (EM), feed intake (FI) and feed conversion ratio (FCR) values are shown in Table (11). Irrespective of MA, HPHE-diet caused significant improvements in EP \%, EN, EW, EM and FCR as well as significant decrease in FI as compared to LPLE-diet. These results are in harmony with those of Abdel-Rahman (1993); Shrivastav et al., (1993); Zanaty et al. (2001); Yakout et al. (2004) and Garcia et al. (2005)

Fayoum J. Agric. Res. \& Dev., Vol. 31, No.2, July, 2017 
RESPONSE OF JAPANESE QUAIL TO FEED BY ORGANIC

who reported that EP, EW, EM and FCR were improved with increasing dietary CP level. However, Garcia et al., (2005) reported that FI was not significantly affected by dietary CP level. Regardless of diet type, MA supplementation caused significant improvements in EP \% and FCR as well as a significant decrease in FI. Supplementing MA to HPHE-diet had similar EP \%, EN, EW, EM and FCR to the corresponding MA-free diet. The only exception, FI was significantly decreased as compared to the corresponding MA-free diet. On the other hand, supplementing MA to LPLE-diet caused significant improvements in $\mathrm{EP} \%$, EW, EM and FCR except for FI that was significantly decreased as compared to the MA-free diet.

From nutritional point of view, it could be concluded that using MA at a level of $0.15 \%$ in Japanese quail diets containing sub-optimal energy and protein levels helped in reducing microflara count, particularly pathogens and in turn, improving quail performance and immunity. However, using MA at a level of $0.15 \%$ in Japanese quail diets containing optimal energy and protein levels caused an increase in EM and a decrease in FI.

Table (1): Composition and calculated analysis of the experimental startergrower and layer basal diets.

\begin{tabular}{|c|c|c|c|c|}
\hline \multirow{2}{*}{ Ingredients } & \multicolumn{4}{|c|}{ Percentage (\%) } \\
\cline { 2 - 5 } & Starter-grower basal diets & \multicolumn{2}{c|}{ Layer basal diets } \\
\cline { 2 - 5 } & HPHE & LPLE & HPHE & LPLE \\
\hline Yellow Corn, ground & 55.16 & 54.37 & 59.42 & 57.19 \\
\hline Soybean meal (44\% CP) & 33.51 & 34.60 & 25.40 & 25.00 \\
\hline Corn gluten meal (62\% CP) & 8.14 & 3.00 & 7.03 & 2.90 \\
\hline Wheat bran & 0.00 & 5.00 & 0.00 & 6.73 \\
\hline Dicalcium phosphate & 1.58 & 1.58 & 2.30 & 2.26 \\
\hline Limestone & 0.81 & 0.81 & 5.01 & 5.02 \\
\hline Common salt (NaCl) & 0.34 & 0.34 & 0.34 & 0.34 \\
\hline Premix & 0.30 & 0.30 & 0.30 & 0.30 \\
\hline DL-Methionine & 0.03 & 0.00 & 0.05 & 0.11 \\
\hline L-Lysine & 0.13 & 0.00 & 0.15 & 0.15 \\
\hline Total & 100.00 & 100.00 & 100.00 & 100.00 \\
\hline Calculated analysis & \multicolumn{4}{|c}{} \\
\hline CP \% & 24.06 & 22.07 & 20.01 & 18.06 \\
\hline CF \% & 3.54 & 4.37 & 3.83 & 3.90 \\
\hline ME (kcal/kg) & 2913 & 2773 & 2894 & 2769 \\
\hline Ca \% & 0.80 & 0.80 & 2.50 & 2.50 \\
\hline Av. Phosphorus \% & 0.35 & 0.36 & 0.39 & 0.38 \\
\hline L-Lysine \% & 1.30 & 1.20 & 1.10 & 1.10 \\
\hline DL-Methionine \% & 0.50 & 0.46 & 0.45 & 0.45 \\
\hline Methionine + Cyst \% & 0.91 & 0.90 & 0.83 & 0.81 \\
\hline
\end{tabular}

* Starter-grower and layer basal diets were assigned to 2 levels of Malic acid MA $\{0$ \& $0.15 \%(1.5$ kg/ton)\}.

**Vitamins and minerals premix provides per kg of diet: $10000 \mathrm{IU}$ vit. A, $11.0 \mathrm{IU}$ vit. E, $1.1 \mathrm{mg}$ vitamin $\mathrm{K}, 1100 \mathrm{ICU}$ vitamin D3, $5 \mathrm{mg}$ riboflavin, $12 \mathrm{mg}$ Ca pantothenate, $12.1 \mu \mathrm{gg}$ vit. B12, $2.2 \mathrm{mg}$ vit. B6, $2.2 \mathrm{mg}$ thiamin, $44 \mathrm{mg}$ nicotinic acid, $250 \mathrm{mg}$ choline chloride, $1.55 \mathrm{mg}$ folic acid, $0.11 \mathrm{mg} \mathrm{d}-$ biotin, $60 \mathrm{mg}$ Mn, $50 \mathrm{mg}$ Zn, 0.3mg I, 0. $1 \mathrm{mg}$ Co, $30 \mathrm{mg}$ Fe, $5 \mathrm{mg}$ Cu and $1 \mathrm{mg}$ Se.

***According to Feed Composition Tables for animal \& poultry feedstuffs used in Egypt (2001).

Fayoum J. Agric. Res. \& Dev., Vol. 31, No.2, July, 2017 
M.A.A. Abdel-Mageed and E.M. EL-Kamash

180

Table (2): Effect of dietary treatments on performance of growing Japanese quail during $1-5$ weeks of age.

\begin{tabular}{|c|c|c|c|c|c|c|c|c|c|c|}
\hline $\begin{array}{c}\text { Items } \\
\text { Treatments } \\
(24 \% \text { Cp) }\end{array}$ & $\begin{array}{c}\text { Initial } \\
\text { BW } \\
\text { (g/bird) }\end{array}$ & $\begin{array}{c}\text { Final BW } \\
\text { (g/bird) }\end{array}$ & $\begin{array}{c}\text { BWG } \\
\text { (g/bird/35d) }\end{array}$ & $\begin{array}{c}\text { FI } \\
(\mathrm{g} / \mathrm{bird} / \mathbf{3 5 d})\end{array}$ & $\begin{array}{l}\text { FCR } \\
\text { (feed: } \\
\text { gain) }\end{array}$ & $\begin{array}{c}\text { PI } \\
\text { (g/bird/d) }\end{array}$ & $\begin{array}{c}\text { CI } \\
\text { (kcal/bird/d) }\end{array}$ & $\begin{array}{c}\text { PCR } \\
\text { (protein: } \\
\text { gain) }\end{array}$ & $\begin{array}{l}\text { CCR } \\
\text { (kcal: } \\
\text { gain) }\end{array}$ & $\begin{array}{l}\text { MR } \\
(\%)\end{array}$ \\
\hline \multicolumn{11}{|c|}{ Energy effects } \\
\hline HPHE-diet & $7.81 \pm 0.09$ & $192.41 \pm 3.12^{A}$ & $184.60 \pm 1.40^{A}$ & $512.76 \pm 4.16^{\mathrm{B}}$ & $2.78 \pm 0.09^{\mathrm{B}}$ & $3.52 \pm 0.05^{A}$ & $42.49 \pm 2.04^{A}$ & $0.67 \pm 0.03^{A}$ & $8.06 \pm 0.05^{A}$ & $3.66 \pm 0.05^{\mathrm{B}}$ \\
\hline LPLE-diet & $7.84 \pm 0.04$ & $167.03 \pm 3.06^{\mathrm{B}}$ & $159.19 \pm 1.28^{\mathrm{B}}$ & $460.30 \pm 4.21^{\mathrm{A}}$ & $2.89 \pm 0.04^{\mathrm{A}}$ & $3.16 \pm 0.04^{\mathrm{B}}$ & $38.14 \pm 2.10^{B}$ & $0.69 \pm 0.04^{\mathrm{B}}$ & $8.39 \pm 0.09^{B}$ & $5.32 \pm 0.04^{\mathrm{A}}$ \\
\hline \multicolumn{11}{|c|}{ Acid effects } \\
\hline $\begin{array}{c}\text { Malic acid } \\
(0.0 \mathrm{~kg} / \mathrm{kg} \text { diet })\end{array}$ & $7.83 \pm 0.03$ & $173.78 \pm 2.89^{\mathrm{B}}$ & $165.95 \pm 1.33^{\mathrm{B}}$ & $496.91 \pm 3.88^{\mathrm{A}}$ & $2.99 \pm 0.05^{\mathrm{A}}$ & $3.41 \pm 0.06^{\mathrm{A}}$ & $41.17 \pm 2.17^{\mathrm{A}}$ & $0.72 \pm 0.02^{\mathrm{A}}$ & $8.68 \pm 0.11^{\mathrm{A}}$ & $8.10 \pm 0.06^{\mathrm{A}}$ \\
\hline $\begin{array}{c}\text { Malic acid } \\
(0.15 \mathrm{~kg} / \mathrm{kg} \text { diet })\end{array}$ & $7.82 \pm 0.07$ & $185.66 \pm 3.00^{\mathrm{A}}$ & $177.84 \pm 1.17^{\mathrm{A}}$ & $476.15 \pm 2.94^{\mathrm{B}}$ & $2.68 \pm 0.07^{\mathrm{B}}$ & $3.27 \pm 0.03^{\mathrm{A}}$ & $39.45 \pm 2.08^{\mathrm{A}}$ & $0.64 \pm 0.02^{\mathrm{B}}$ & $7.76 \pm 0.07^{\mathrm{B}}$ & $1.01 \pm 0.03^{\mathrm{B}}$ \\
\hline \multicolumn{11}{|c|}{ Interaction } \\
\hline $\begin{array}{c}\text { HPHE } \\
\text {-diet x } 0.0\end{array}$ & $7.84 \pm 0.06$ & $191.35 \pm .2 .70^{\mathrm{a}}$ & $183.51 \pm 1.20^{\mathrm{a}}$ & $523.21 \pm 2.88^{\mathrm{a}}$ & $2.85 \pm 0.03^{b}$ & $3.59 \pm 0.04^{\mathrm{a}}$ & $43.35 \pm 2.12^{\mathrm{a}}$ & $0.68 \pm 0.01^{\mathrm{a}}$ & $8.27 \pm 0.06^{\mathrm{a}}$ & $6.99 \pm 0.05^{b}$ \\
\hline $\begin{array}{c}\text { HPHE } \\
\text {-diet x } 0.15\end{array}$ & $7.78 \pm 0.05$ & $193.47 \pm 3.00^{\mathrm{a}}$ & $185.69 \pm 1.09^{\mathrm{a}}$ & $502.30 \pm 4.01^{b}$ & $2.71 \pm 0.05^{\mathrm{b}}$ & $3.44 \pm 0.02^{\mathrm{a}}$ & $41.62 \pm 2.34^{\mathrm{a}}$ & $0.65 \pm 0.05^{\mathrm{a}}$ & $7.84 \pm 0.09^{\mathrm{a}}$ & $0.99 \pm 0.04^{\mathrm{c}}$ \\
\hline $\begin{array}{c}\text { LPLE } \\
\text {-diet } x \text { 0.0 }\end{array}$ & $7.81 \pm 0.03$ & $156.20 \pm 2.90^{\mathrm{c}}$ & $148.39 \pm 1.23^{\mathrm{c}}$ & $470.61 \pm 3.29^{\mathrm{c}}$ & $3.17 \pm 0.09^{\mathrm{a}}$ & $3.23 \pm 0.01^{b}$ & $38.99 \pm 2.29^{\mathrm{b}}$ & $0.76 \pm 0.02^{\mathrm{a}}$ & $9.20 \pm 0.08^{\mathrm{a}}$ & $9.21 \pm 0.02^{\mathrm{a}}$ \\
\hline $\begin{array}{c}\text { LPLE } \\
\text {-diet x } 0.15\end{array}$ & $7.86 \pm 0.07$ & $177.85 \pm 2.22^{\mathrm{b}}$ & $169.99 \pm 1.29^{\mathrm{b}}$ & $449.99 \pm 4.10^{\mathrm{d}}$ & $2.65 \pm 0.06^{\mathrm{b}}$ & $3.09 \pm 0.03^{\mathrm{b}}$ & $37.28 \pm 2.40^{\mathrm{b}}$ & $0.64 \pm 0.02^{b}$ & $7.88 \pm 0.11^{b}$ & $1.43 \pm 0.04^{c}$ \\
\hline
\end{tabular}

Means in the same column within the same effect having different letters are significantly different at $\mathbf{P} \leq \mathbf{0 . 0 5}$.

BW $=$ Body weight conversion ratio CI = caloric intake MR = mortality rate

HPHE-diet $=$ recommended protein and recommended energy low energy

$$
\begin{aligned}
& \text { BWG = Body weight gain } \quad \text { FI }=\text { Feed intake } \quad \text { FCR }=\text { Feed } \\
& \begin{array}{l}
\text { PI = protein intake } \\
\text { PCR = protein conversion ratio }
\end{array} \quad \text { CCR = caloric conversion ratio }
\end{aligned}
$$

\begin{tabular}{|c|c|c|c|c|c|c|}
\hline \multirow{2}{*}{\begin{tabular}{|c|} 
Items \\
Treatments $(24 \% \mathrm{Cp})$ \\
\end{tabular}} & \multicolumn{6}{|c|}{ (\% of BW) } \\
\hline & $\begin{array}{c}\text { BW } \\
\text { (g/bird) }\end{array}$ & $\begin{array}{c}\text { Eviscerated } \\
\text { carcass }\end{array}$ & Dressing $^{*}$ & Breast & $\begin{array}{c}\text { Abdominal } \\
\text { fat }\end{array}$ & Ovary-oviduct \\
\hline \multicolumn{7}{|c|}{ Energy effects } \\
\hline HPHE-diet & $190.77 \pm 2.01^{\mathrm{A}}$ & $68.68 \pm 2.04^{\mathrm{A}}$ & $75.22 \pm 0.83^{\mathrm{A}}$ & $37.85 \pm 1.04^{\mathrm{A}}$ & $2.29 \pm 0.05^{\mathrm{B}}$ & $8.45 \pm 0.05^{\mathrm{A}}$ \\
\hline LPLE-diet & $163.91 \pm 2.55^{\mathrm{B}}$ & $61.43 \pm 2.10^{\mathrm{B}}$ & $67.38 \pm 0.75^{\mathrm{B}}$ & $29.14 \pm 1.10^{\mathrm{B}}$ & $2.81 \pm 0.02^{\mathrm{A}}$ & $5.77 \pm 0.09^{\mathrm{B}}$ \\
\hline \multicolumn{7}{|c|}{ Acid effects } \\
\hline Malic acid (0.0kg/kg diet) & $171.16 \pm 2.05^{\mathrm{B}}$ & $63.45 \pm 2.17$ & $69.89 \pm 0.85$ & $31.96 \pm 1.17$ & $2.84 \pm 0.03^{\mathrm{A}}$ & $6.79 \pm 0.11^{\mathrm{B}}$ \\
\hline Malic acid $(0.15 \mathrm{~kg} / \mathrm{kg}$ diet $)$ & $183.53 \pm 2.31^{\mathrm{A}}$ & $65.67 \pm 2.08$ & $72.26 \pm 0.80$ & $28.97 \pm 1.08$ & $2.26 \pm 0.04^{\mathrm{B}}$ & $7.42 \pm 0.07^{\mathrm{A}}$ \\
\hline \multicolumn{7}{|c|}{ Interaction } \\
\hline HPHE-diet x 0.0 & $189.22 \pm 2.11^{\mathrm{a}}$ & $68.61 \pm 2.12^{\mathrm{a}}$ & $75.65 \pm 0.47^{\mathrm{a}}$ & $37.71 \pm 1.12^{\mathrm{a}}$ & $2.36 \pm 0.02^{b}$ & $8.38 \pm 0.06^{\mathrm{a}}$ \\
\hline HPHE-diet x 0.15 & $192.31 \pm 2.05^{\mathrm{a}}$ & $68.76 \pm 2.34^{\mathrm{a}}$ & $74.81 \pm 0.92^{\mathrm{a}}$ & $38.00 \pm 1.34^{\mathrm{a}}$ & $2.21 \pm 0.03^{\mathrm{b}}$ & $8.52 \pm 0.09^{\mathrm{a}}$ \\
\hline LPLE-diet x 0.0 & $153.10 \pm 2.25^{\mathrm{c}}$ & $59.29 \pm 2.09^{c}$ & $65.10 \pm 0.44^{\mathrm{c}}$ & $26.22 \pm 1.29^{c}$ & $3.31 \pm 0.07^{\mathrm{a}}$ & $5.20 \pm 0.08^{\mathrm{c}}$ \\
\hline LPLE-diet x 0.15 & $174.73 \pm 3.01^{\mathrm{b}}$ & $63.58 \pm 2.20^{\mathrm{b}}$ & $69.65 \pm 0.77^{b}$ & $32.09 \pm 1.40^{\mathrm{b}}$ & $2.30 \pm 0.04^{b}$ & $6.33 \pm 0.11^{b}$ \\
\hline
\end{tabular}

Table (3): Effect of dietary treatments on carcass characteristics of Japanese quail at 5 weeks of age.

* Dressing \% $=[($ Carcass weight + Giblets weight $) /($ Pre-slaughter weight $)] \times 100 . \quad$ BW : body weight

Means in the same column within the same effect having different letters are significantly different at $\mathbf{P} \leq \mathbf{0 . 0 5}$. 
RESPONSE OF JAPANESE QUAIL TO FEED BY ORGANIC.

Table (4): Effect of dietary treatments on edible giblets and lymphoid organs \% of Japanese quail at 5 weeks of age.

\begin{tabular}{|c|c|c|c|c|c|c|}
\hline \multirow{2}{*}{$\begin{array}{c}\text { Items } \\
\text { Treatments }(24 \% \text { Cp) } \\
\end{array}$} & \multicolumn{3}{|c|}{ Edible giblets (\%) } & \multicolumn{3}{|c|}{ lymphoid organs (\%) } \\
\hline & $\begin{array}{c}\text { Gizzard } \\
(\%)\end{array}$ & $\begin{array}{c}\text { Heart } \\
(\%)\end{array}$ & $\begin{array}{c}\text { Liver } \\
(\%)\end{array}$ & $\begin{array}{c}\text { Spleen } \\
(\%)\end{array}$ & $\begin{array}{c}\text { Bursa } \\
(\%)\end{array}$ & $\begin{array}{c}\text { Thymus } \\
(\%)\end{array}$ \\
\hline \multicolumn{7}{|c|}{ Energy effects } \\
\hline HPHE-diet & $3.05 \pm 0.19$ & $1.05 \pm 0.09^{\mathrm{A}}$ & $3.05 \pm 0.19^{\mathrm{A}}$ & $0.14 \pm 0.03$ & $0.15 \pm 0.02$ & $0.31 \pm 0.03$ \\
\hline LPLE-diet & $3.06 \pm 0.14$ & $0.84 \pm 0.04^{\mathrm{B}}$ & $2.14 \pm 0.14^{\mathrm{B}}$ & $0.12 \pm 0.02$ & $0.13 \pm 0.03$ & $0.31 \pm 0.02$ \\
\hline \multicolumn{7}{|c|}{ Acid effects } \\
\hline Malic acid (0.0kg/kg diet) & $3.05 \pm 0.15$ & $0.92 \pm 0.09$ & $2.55 \pm 0.19$ & $0.13 \pm 0.01$ & $0.19 \pm 0.03$ & $0.22 \pm 0.03^{\mathrm{B}}$ \\
\hline Malic acid $(0.15 \mathrm{~kg} / \mathrm{kg}$ diet $)$ & $3.07 \pm 0.14$ & $0.96 \pm 0.04$ & $2.65 \pm 0.14$ & $0.17 \pm 0.02$ & $0.17 \pm 0.01$ & $0.40 \pm 0.02^{\mathrm{A}}$ \\
\hline \multicolumn{7}{|c|}{ Interaction } \\
\hline HPHE-diet x 0.0 & $3.04 \pm 0.14^{\mathrm{a}}$ & $1.03 \pm 0.03^{\mathrm{a}}$ & $3.06 \pm 0.13^{\mathrm{a}}$ & $0.11 \pm 0.02^{\mathrm{b}}$ & $0.09 \pm 0.02^{\mathrm{b}}$ & $0.23 \pm 0.02^{\mathrm{b}}$ \\
\hline HPHE-diet x 0.15 & $3.06 \pm 0.15^{\mathrm{a}}$ & $1.07 \pm 0.05^{\mathrm{a}}$ & $3.04 \pm 0.15^{\mathrm{a}}$ & $0.16 \pm 0.03^{\mathrm{a}}$ & $0.20 \pm 0.02^{\mathrm{a}}$ & $0.39 \pm 0.03^{\mathrm{a}}$ \\
\hline LPLE-diet x 0.0 & $3.05 \pm 0.13^{\mathrm{a}}$ & $0.82 \pm 0.09^{b}$ & $2.13 \pm 0.19^{b}$ & $0.09 \pm 0.03^{b}$ & $0.08 \pm 0.01^{\mathrm{b}}$ & $0.21 \pm 0.03^{\mathrm{b}}$ \\
\hline LPLE-diet x 0.15 & $3.07 \pm 0.11^{\mathrm{a}}$ & $0.85 \pm 0.06^{\mathrm{b}}$ & $2.25 \pm 0.16^{\mathrm{b}}$ & $0.15 \pm 0.02^{\mathrm{a}}$ & $0.17 \pm 0.02^{\mathrm{a}}$ & $0.41 \pm 0.02^{\mathrm{a}}$ \\
\hline
\end{tabular}

Means in the same column within the same effect having different letters are significantly different at $\mathbf{P} \leq \mathbf{0 . 0 5}$.

Table (5): Effect of dietary treatments on the intestinal villi of growing Japanese quail at 5 weeks of age.

\begin{tabular}{|c|c|c|c|c|c|c|}
\hline \multirow{3}{*}{$\begin{array}{c}\text { Items } \\
\text { Treatments }(24 \% \mathrm{Cp})\end{array}$} & \multicolumn{6}{|c|}{ Intestinal segment } \\
\hline & \multicolumn{2}{|c|}{ Ileum } & \multicolumn{2}{|c|}{ Duodenum } & \multicolumn{2}{|c|}{ Jejunum } \\
\hline & $\begin{array}{c}\text { Villus height } \\
\text { (um) }\end{array}$ & $\begin{array}{c}\text { Villus Width } \\
\text { (um) }\end{array}$ & $\begin{array}{c}\text { Villus height } \\
\text { (um) }\end{array}$ & $\begin{array}{l}\text { Villus Width } \\
\text { (um) }\end{array}$ & $\begin{array}{l}\text { Villus height } \\
\text { (um) }\end{array}$ & $\begin{array}{c}\text { Villus Width } \\
\text { (um) }\end{array}$ \\
\hline \multicolumn{7}{|c|}{ Energy effects } \\
\hline HPHE-diet & $226.96 \pm 2.11$ & $98.46 \pm 1.18$ & $467.66 \pm 4.55$ & $113.41 \pm 2.01$ & $343.46 \pm 4.11$ & $103.57 \pm 2.12$ \\
\hline LPLE-diet & $233.81 \pm 2.01$ & $103.26 \pm 1.04$ & $468.01 \pm 3.88$ & $112.91 \pm 2.22$ & $337.16 \pm 3.45$ & $107.66 \pm 2.06$ \\
\hline \multicolumn{7}{|c|}{ Acid effects } \\
\hline \begin{tabular}{|l} 
Malic acid (0.0kg/kg diet) \\
\end{tabular} & $210.61 \pm 2.15^{\mathrm{B}}$ & $93.21 \pm 1.06^{\mathrm{B}}$ & $451.81 \pm 3.71^{\mathrm{B}}$ & $103.71 \pm 2.16^{\mathrm{B}}$ & $321.71 \pm 3.81^{\mathrm{B}}$ & $94.91 \pm 2.11^{\mathrm{B}}$ \\
\hline Malic acid $(0.15 \mathrm{~kg} / \mathrm{kg}$ diet $)$ & $250.16 \pm 2.05^{\mathrm{A}}$ & $108.51 \pm 1.10^{\mathrm{A}}$ & $483.86 \pm 5.01^{\mathrm{A}}$ & $122.61 \pm 3.14^{\mathrm{A}}$ & $359.21 \pm 3.31^{\mathrm{A}}$ & $116.31 \pm 2.10^{\mathrm{A}}$ \\
\hline \multicolumn{7}{|c|}{ Interaction } \\
\hline HPHE-diet x 0.0 & $206.71 \pm 2.12^{b}$ & $91.31 \pm 1.15^{\mathrm{b}}$ & $448.21 \pm 2.10^{\mathrm{a}}$ & $101.31 \pm 1.11^{\mathrm{b}}$ & $324.81 \pm 3.02^{b}$ & $92.21 \pm 2.12^{b}$ \\
\hline HPHE-diet x 0.15 & $247.21 \pm 2.04^{\mathrm{a}}$ & $105.61 \pm 1.08^{\mathrm{a}}$ & $487.11 \pm 5.01^{\mathrm{b}}$ & $125.51 \pm 3.02^{\mathrm{a}}$ & $362.11 \pm 4.01^{\mathrm{a}}$ & $114.91 \pm 3.02^{\mathrm{a}}$ \\
\hline LPLE-diet x 0.0 & $214.51 \pm 1.09^{b}$ & $95.11 \pm 1.10^{\mathrm{b}}$ & $455.41 \pm 4.01^{\mathrm{a}}$ & $106.11 \pm 2.24^{\mathrm{b}}$ & $318.61 \pm 2.13^{\mathrm{b}}$ & $97.61 \pm 2.11^{\mathrm{b}}$ \\
\hline LPLE-diet x 0.15 & $253.11 \pm 1.05^{\mathrm{a}}$ & $111.41 \pm 1.30^{\mathrm{a}}$ & $480.61 \pm 3.21^{\mathrm{b}}$ & $119.71 \pm 4.01^{\mathrm{a}}$ & $356.31 \pm 5.03^{\mathrm{a}}$ & $117.71 \pm 1.23^{\mathrm{a}}$ \\
\hline
\end{tabular}

Means in the same column within the same effect having different letters are significantly different at $\mathbf{P} \leq \mathbf{0 . 0 5}$.

Fayoum J. Agric. Res. \& Dev., Vol. 31, No.2, July, 2017 
Table (6): Effect of dietary treatments on total microflora count, colibacillus, lactobacillus and their ratio of the ileum content as well as intestinal pH of Japanese quail at 5 weeks of age.

\begin{tabular}{|c|c|c|c|c|c|}
\hline \multirow{2}{*}{\begin{tabular}{|c|} 
Items \\
Treatments $(24 \%$ Cp) \\
\end{tabular}} & \multicolumn{3}{|c|}{ Microflora count (Log No/g) } & \multirow[b]{2}{*}{$\begin{array}{c}\text { Lactobacillus } \\
\text { Colibacillus } \\
\text { ratio }\end{array}$} & \multirow[b]{2}{*}{ Intestinal pH } \\
\hline & $\begin{array}{c}\text { Total } \\
\text { Microflora } \\
\text { count }\end{array}$ & Lactobacillus & Colibacillus & & \\
\hline \multicolumn{6}{|c|}{ Energy effects } \\
\hline HPHE-diet & $9.62 \pm 0.06$ & $5.36 \pm 0.15$ & $5.47 \pm 0.06$ & $0.98 \pm 0.12$ & $6.55 \pm 0.19$ \\
\hline LPLE-diet & $9.78 \pm 0.14$ & $5.38 \pm 0.11$ & $5.45 \pm 0.10$ & $0.99 \pm 0.14$ & $6.60 \pm 0.04$ \\
\hline \multicolumn{6}{|c|}{ Acid effects } \\
\hline Malic acid (0.0kg/kg diet) & $11.03 \pm 0.08^{\mathrm{A}}$ & $4.46 \pm 0.10^{\mathrm{B}}$ & $6.37 \pm 0.05^{\mathrm{A}}$ & $0.70 \pm 0.10$ & $6.90 \pm 0.03^{\mathrm{A}}$ \\
\hline Malic acid $(0.15 \mathrm{~kg} / \mathrm{kg}$ diet $)$ & $8.37 \pm 0.16^{\mathrm{B}}$ & $6.28 \pm 0.11^{\mathrm{A}}$ & $4.55 \pm 0.08^{\mathrm{B}}$ & $1.38 \pm 0.09$ & $6.25 \pm 0.05^{\mathrm{B}}$ \\
\hline \multicolumn{6}{|c|}{ Interaction } \\
\hline HPHE-diet x 0.0 & $10.93 \pm 0.14^{\mathrm{a}}$ & $4.50 \pm 0.17^{\mathrm{b}}$ & $6.31 \pm 0.10^{\mathrm{a}}$ & $0.71 \pm 0.13$ & $6.80 \pm 0.08$ \\
\hline HPHE-diet x 0.15 & $8.31 \pm 0.08^{\mathrm{b}}$ & $6.21 \pm 0.15^{\mathrm{a}}$ & $4.63 \pm 0.13^{\mathrm{b}}$ & $1.34 \pm 0.11$ & $6.30 \pm 0.07$ \\
\hline LPLE-diet x 0.0 & $11.13 \pm 0.13^{\mathrm{a}}$ & $4.41 \pm 0.10^{\mathrm{b}}$ & $6.43 \pm 0.13^{\mathrm{a}}$ & $0.69 \pm 0.10$ & $7.00 \pm 0.05$ \\
\hline LPLE-diet x 0.15 & $8.42 \pm 0.12^{b}$ & $6.34 \pm 0.12^{\mathrm{a}}$ & $4.47 \pm 0.11^{b}$ & $1.42 \pm 0.14$ & $6.20 \pm 0.04$ \\
\hline
\end{tabular}

Means in the same column within the same effect having different letters are significantly different at $\mathbf{P} \leq \mathbf{0 . 0 5}$.

Table (7): Effect of dietary treatments on some serum blood parameters of growing Japanese quail at 5 weeks of age.

\begin{tabular}{|c|c|c|c|c|c|c|}
\hline Treatments $(24 \%$ Cp) & $\begin{array}{c}\text { TP } \\
(\mathrm{g} / 100 \mathrm{ml})\end{array}$ & $\underset{(\mathrm{g} / 100 \mathrm{ml})}{\text { Alb }}$ & $\begin{array}{c}\text { Glo } \\
(\mathrm{g} / 100 \mathrm{ml})\end{array}$ & $\begin{array}{c}\text { Alb/Glo } \\
\text { ratio }\end{array}$ & $\begin{array}{c}\text { TL } \\
(\mathrm{g} / 100 \mathrm{ml})\end{array}$ & $\begin{array}{c}\text { Cho } \\
(\mathrm{g} / 100 \mathrm{ml})\end{array}$ \\
\hline \multicolumn{7}{|c|}{ Energy effects } \\
\hline HPHE-diet & $4.51 \pm 0.08$ & $1.99 \pm 0.07^{\mathrm{A}}$ & $2.62 \pm 0.14^{\mathrm{B}}$ & $0.75 \pm 0.04^{\mathrm{A}}$ & $1.65 \pm 0.15^{\mathrm{B}}$ & $108.66 \pm 5.34$ \\
\hline LPLE-diet & $4.52 \pm 0.11$ & $1.14 \pm 0.09^{\mathrm{B}}$ & $3.48 \pm 0.12^{\mathrm{A}}$ & $0.33 \pm 0.09^{\mathrm{B}}$ & $2.08 \pm 0.14^{\mathrm{A}}$ & $107.79 \pm 7.99$ \\
\hline \multicolumn{7}{|c|}{ Acid effects } \\
\hline Malic acid (0.0kg/kg diet) & $4.50 \pm 0.09$ & $1.56 \pm 0.04$ & $3.04 \pm 0.15$ & $0.51 \pm 0.13$ & $1.87 \pm 0.05$ & $109.67 \pm 4.99$ \\
\hline Malic acid (0.15kg/kg diet) & $4.53 \pm 0.12$ & $1.57 \pm 0.11$ & $3.06 \pm 0.05$ & $0.51 \pm 0.11$ & $1.86 \pm 0.08$ & $106.78 \pm 6.22$ \\
\hline \multicolumn{7}{|c|}{ Interaction } \\
\hline HPHE-diet x 0.0 & $4.50 \pm 0.06$ & $2.01 \pm 0.11^{\mathrm{a}}$ & $2.59 \pm 0.16^{\mathrm{b}}$ & $0.78 \pm 0.16^{\mathrm{a}}$ & $1.63 \pm 0.14^{\mathrm{b}}$ & $110.10 \pm 7.11$ \\
\hline HPHE-diet x 0.15 & $4.52 \pm 0.11$ & $1.96 \pm 0.13^{\mathrm{a}}$ & $2.66 \pm 0.13^{b}$ & $0.74 \pm 0.15^{\mathrm{a}}$ & $1.66 \pm 0.13^{\mathrm{b}}$ & $107.21 \pm 6.11$ \\
\hline LPLE-diet x 0.0 & $4.50 \pm 0.06$ & $1.10 \pm 0.11^{\mathrm{b}}$ & $3.50 \pm 0.11^{\mathrm{a}}$ & $0.31 \pm 0.03^{\mathrm{b}}$ & $2.10 \pm 0.11^{\mathrm{a}}$ & $109.24 \pm 5.17$ \\
\hline LPLE-diet x 0.15 & $4.53 \pm 0.11$ & $1.17 \pm 0.14^{\mathrm{b}}$ & $3.46 \pm 0.18^{\mathrm{a}}$ & $0.34 \pm 0.12^{\mathrm{b}}$ & $2.06 \pm 0.17^{\mathrm{a}}$ & $106.34 \pm 7.00$ \\
\hline
\end{tabular}

Means in the same column within the same effect having different letters are significantly different at $\mathbf{P} \leq \mathbf{0 . 0 5}$.

TP : total protein

Alb : albumin

Glo : globulin

TL : total lipids

Cho : cholesterol

Fayoum J. Agric. Res. \& Dev., Vol. 31, No.2, July, 2017 
RESPONSE OF JAPANESE QUAIL TO FEED BY ORGANIC

Table (8): Effect of dietary treatments on the digestibility coefficients of growing Japanese quail at 5 weeks of age.

\begin{tabular}{|c|c|c|c|c|}
\hline \multirow{2}{*}{$\begin{array}{c}\text { Items } \\
\text { Treatments }(24 \% \mathrm{Cp})\end{array}$} & \multicolumn{4}{|c|}{ Digestibility coefficients $(\%)$} \\
\hline & $\mathbf{C P}$ & $\mathbf{C F}$ & $\mathbf{E E}$ & NFE \\
\hline \multicolumn{5}{|c|}{ Energy effects } \\
\hline HPHE-diet & $91.13 \pm 1.23^{\mathrm{A}}$ & $21.20 \pm 1.11$ & $74.69 \pm 1.19^{\mathrm{A}}$ & $79.27 \pm 1.09$ \\
\hline LPLE-diet & $82.08 \pm 1.14^{\mathrm{B}}$ & $21.20 \pm 1.07$ & $68.72 \pm 1.31^{\mathrm{B}}$ & $79.27 \pm 1.04$ \\
\hline \multicolumn{5}{|c|}{ Acid effects } \\
\hline Malic acid (0.0kg/kg diet) & $85.91 \pm 1.36^{\mathrm{B}}$ & $21.21 \pm 1.22$ & $71.88 \pm 1.15$ & $79.29 \pm 1.24$ \\
\hline Malic acid (0.15kg/kg diet) & $88.31 \pm 1.16^{\mathrm{A}}$ & $21.19 \pm 1.21$ & $71.53 \pm 1.1$ & $79.25 \pm 1.31$ \\
\hline \multicolumn{5}{|c|}{ Interaction } \\
\hline HPHE-diet x 0.0 & $91.11 \pm 1.14^{\mathrm{a}}$ & $21.19 \pm 1.14$ & $74.62 \pm 1.34^{\mathrm{a}}$ & $79.30 \pm 1.22$ \\
\hline HPHE-diet x 0.15 & $91.15 \pm 1.15^{\mathrm{a}}$ & $21.21 \pm 1.15$ & $74.76 \pm 1.25^{\mathrm{a}}$ & $79.24 \pm 1.11$ \\
\hline LPLE-diet x 0.0 & $80.70 \pm 1.11^{\mathrm{c}}$ & $21.23 \pm 1.33$ & $69.14 \pm 1.13^{b}$ & $79.27 \pm 1.33$ \\
\hline LPLE-diet x 0.15 & $85.46 \pm 1.21^{\mathrm{b}}$ & $21.17 \pm 1.29$ & $68.29 \pm 1.31^{b}$ & $79.26 \pm 1.13$ \\
\hline
\end{tabular}

Means in the same column within the same effect having different letters are significantly different at $\mathbf{P} \leq \mathbf{0 . 0 5}$.

CP : crude protein

CF : crude fiber

$\mathbf{E E}$ : ether extract

NFE : nitrogen free extract

Table (9): Effect of dietary treatments on egg analysis of laying Japanese quail from 7 to 19 weeks of age.

\begin{tabular}{|c|c|c|c|c|}
\hline Items & $\begin{array}{c}\text { ALb }_{\mathbf{p}} \\
(\%)\end{array}$ & $\begin{array}{c}\mathbf{Y}_{\mathbf{p}} \\
(\%)\end{array}$ & $\begin{array}{c}\mathbf{Y}_{\mathbf{E E}} \\
(\%)\end{array}$ & $\begin{array}{c}\mathbf{Y}_{\text {cho }} \\
\text { Treatments(20\% Cp) }\end{array}$ \\
\hline \multicolumn{5}{|c|}{ Energy effects } \\
\hline HPHE-diet & $80.80 \pm 0.50$ & $32.77 \pm 0.70^{\mathrm{A}}$ & $59.04 \pm 0.50^{\mathrm{B}}$ & $23.46 \pm 0.39^{\mathrm{B}}$ \\
\hline LPLE-diet & $80.70 \pm 0.90$ & $31.02 \pm 0.60^{\mathrm{B}}$ & $61.62 \pm 0.90^{\mathrm{A}}$ & $25.66 \pm 0.60^{\mathrm{A}}$ \\
\hline \multicolumn{5}{|c|}{ Acid effects } \\
\hline Malic acid (0.0kg/kg diet) & $80.70 \pm 0.56$ & $31.83 \pm 0.81$ & $60.25 \pm 0.77$ & $26.14 \pm 0.47^{\mathrm{A}}$ \\
\hline Malic acid (0.15kg/kg diet) & $80.80 \pm 0.71$ & $31.95 \pm 0.72$ & $60.41 \pm 0.80$ & $22.99 \pm 0.32^{\mathrm{B}}$ \\
\hline \multicolumn{5}{|c|}{ Interaction } \\
\hline \multicolumn{7}{|c|}{ HPHE-diet x 0.0 } & $80.78 \pm 0.81$ & $32.72 \pm 0.14^{\mathrm{a}}$ & $58.99 \pm 0.70^{\mathrm{b}}$ & $25.13 \pm 0.47^{\mathrm{a}}$ \\
\hline HPHE-diet x 0.15 & $80.81 \pm 0.77$ & $32.81 \pm 0.15^{\mathrm{a}}$ & $59.09 \pm 0.65^{\mathrm{b}}$ & $21.81 \pm 0.77^{\mathrm{b}}$ \\
\hline LPLE-diet x 0.0 & $80.62 \pm 0.68$ & $30.94 \pm 0.13^{\mathrm{b}}$ & $61.51 \pm 0.59^{\mathrm{a}}$ & $27.15 \pm 0.81^{\mathrm{a}}$ \\
\hline LPLE-diet x 0.15 & $80.78 \pm 0.52$ & $31.09 \pm 0.11^{\mathrm{b}}$ & $61.72 \pm 0.80^{\mathrm{a}}$ & $24.16 \pm 0.51^{\mathrm{b}}$ \\
\hline
\end{tabular}

Means in the same column within the same effect having different letters are significantly different at $\mathbf{P} \leq \mathbf{0 . 0 5}$.
$A L b_{p}$ : albumin protein
$Y_{p}$ : yolk protein
$\mathbf{Y}_{\mathrm{EE}}$ : yolk ether extract

$\mathbf{Y}_{\text {cho }}$ : yolk cholesterol

Fayoum J. Agric. Res. \& Dev., Vol. 31, No.2, July, 2017 
M.A.A. Abdel-Mageed and E.M. EL-Kamash

Table (10): Effect of dietary treatments on egg quality of laying Japanese quail from 7 to 19 weeks of age.

\begin{tabular}{|c|c|c|c|c|c|c|}
\hline \multirow{2}{*}{$\begin{array}{c}\text { Items } \\
\text { Treatments }(20 \% \mathrm{Cp})\end{array}$} & \multirow[b]{2}{*}{$\begin{array}{c}\text { STh } \\
\text { (u) }\end{array}$} & \multirow[b]{2}{*}{$\begin{array}{l}\text { ESI } \\
(\%)\end{array}$} & \multirow[b]{2}{*}{$\begin{array}{c}\text { ESG } \\
(\mathrm{mg} / \mathrm{cm}))\end{array}$} & \multicolumn{3}{|c|}{$\%$ of EW } \\
\hline & & & & Alb & $\mathbf{S}$ & $\mathbf{Y}$ \\
\hline \multicolumn{7}{|c|}{ Energy effects } \\
\hline HPHE-diet & $322.66 \pm 0.04^{\mathrm{A}}$ & $79.60 \pm 0.17^{\mathrm{A}}$ & $1.16 \pm 0.02$ & $61.04 \pm 0.55$ & $11.58 \pm 0.07^{\mathrm{A}}$ & $31.31 \pm 0.23^{\mathrm{B}}$ \\
\hline LPLE-diet & $258.47 \pm 0.02^{\mathrm{B}}$ & $70.10 \pm 0.19^{\mathrm{B}}$ & $1.16 \pm 0.01$ & $58.04 \pm 0.73$ & $10.40 \pm 0.12^{\mathrm{B}}$ & $34.48 \pm 0.20^{\mathrm{A}}$ \\
\hline \multicolumn{7}{|c|}{ Acid effects } \\
\hline $\begin{array}{c}\text { Malic acid }(0.0 \mathrm{~kg} / \mathrm{kg} \\
\text { diet) }\end{array}$ & $261.80 \pm 0.02^{\mathrm{B}}$ & $72.60 \pm 0.22^{\mathrm{B}}$ & $1.13 \pm 0.01$ & $59.23 \pm 0.68$ & $10.82 \pm 0.11^{\mathrm{B}}$ & $32.92 \pm 0.24$ \\
\hline $\begin{array}{c}\text { Malic acid }(0.15 \mathrm{~kg} / \mathrm{kg} \\
\text { diet) }\end{array}$ & $319.32 \pm 0.01^{\mathrm{A}}$ & $77.10 \pm 0.12^{\mathrm{A}}$ & $1.19 \pm 0.03$ & $59.85 \pm 0.70$ & $11.16 \pm 0.09^{\mathrm{A}}$ & $32.87 \pm 0.20$ \\
\hline \multicolumn{7}{|c|}{ Interaction } \\
\hline HPHE-diet x 0.0 & $322.40 \pm 0.02^{\mathrm{a}}$ & $79.10 \pm 0.20^{\mathrm{a}}$ & $1.13 \pm 0.01$ & $60.57 \pm 0.80$ & $11.54 \pm 0.11^{\mathrm{a}}$ & $31.19 \pm 0.23^{b}$ \\
\hline HPHE-diet x 0.15 & $322.91 \pm 0.01^{\mathrm{a}}$ & $80.10 \pm 0.18^{\mathrm{a}}$ & $1.18 \pm 0.02$ & $61.50 \pm 0.92$ & $11.61 \pm 0.11^{\mathrm{a}}$ & $31.42 \pm 0.41^{\mathrm{b}}$ \\
\hline LPLE-diet x 0.0 & $201.20 \pm 0.03^{\mathrm{b}}$ & $66.10 \pm 0.21^{\mathrm{c}}$ & $1.12 \pm 0.02$ & $57.88 \pm 0.74$ & $10.10 \pm 0.13^{\mathrm{c}}$ & $34.64 \pm 0.31^{\mathrm{a}}$ \\
\hline LPLE-diet x 0.15 & $315.73 \pm 0.01^{\mathrm{a}}$ & $74.10 \pm 0.21^{b}$ & $1.20 \pm 0.02$ & $58.19 \pm 0.60$ & $10.70 \pm 0.11^{\mathrm{a}}$ & $34.31 \pm 0.43^{\mathrm{a}}$ \\
\hline
\end{tabular}

Means in the same column within the same effect having different letters are significantly different at $\mathbf{P} \leq \mathbf{0 . 0 5}$. gravity

STh : shell thickness $\quad$ ESI : egg shape index $\quad$ ESG : egg specific
Alb : albumin weight
S : shell weight
Y : yolk weight

Table (11): Effect of dietary treatments on performance of laying Japanese quail from 7 to 19 weeks of age.

\begin{tabular}{|c|c|c|c|c|c|c|}
\hline Treatments $(20 \%$ Cp) & $\begin{array}{l}\text { EP } \\
(\%)\end{array}$ & $\begin{array}{c}\text { EN } \\
\text { (No./hen/day) }\end{array}$ & $\begin{array}{c}\text { EW } \\
(\mathrm{g})\end{array}$ & $\begin{array}{c}\text { EM } \\
\text { (g/hen/day) }\end{array}$ & $\begin{array}{c}\text { FI } \\
\text { (g/hen/day) }\end{array}$ & $\begin{array}{c}\text { FCR } \\
\text { (g feed/g egg) }\end{array}$ \\
\hline \multicolumn{7}{|c|}{ Energy effects } \\
\hline HPHE-diet & $83.03 \pm 2.90^{A}$ & $0.87 \pm 0.04^{A}$ & $11.21 \pm 0.04^{\mathrm{A}}$ & $9.75 \pm 0.04^{\mathrm{A}}$ & $20.23 \pm 0.19^{\mathrm{B}}$ & $2.07 \pm 0.01^{\mathrm{B}}$ \\
\hline LPLE-diet & $76.17 \pm 2.21^{B}$ & $0.82 \pm 0.07^{\mathrm{B}}$ & $9.57 \pm 0.07^{\mathrm{B}}$ & $7.85 \pm 0.07^{\mathrm{B}}$ & $22.37 \pm 0.25^{\mathrm{A}}$ & $2.85 \pm 0.03^{\mathrm{A}}$ \\
\hline \multicolumn{7}{|c|}{ Acid effects } \\
\hline Malic acid (0.0kg/kg diet) & $78.16 \pm 3.10^{B}$ & $0.84 \pm 0.04$ & $10.12 \pm 0.04$ & $8.50 \pm 0.04$ & $22.47 \pm 0.31^{\mathrm{A}}$ & $2.64 \pm 0.02^{A}$ \\
\hline Malic acid $(0.15 \mathrm{~kg} / \mathrm{kg}$ diet $)$ & $81.04 \pm 2.71^{\mathrm{A}}$ & $0.85 \pm 0.05$ & $10.66 \pm 0.08$ & $9.10 \pm 0.08$ & $20.13 \pm 0.14^{\mathrm{B}}$ & $2.21 \pm 0.01^{\mathrm{B}}$ \\
\hline \multicolumn{7}{|c|}{ Interaction } \\
\hline HPHE-diet x 0.0 & $83.17 \pm 3.21^{\mathrm{a}}$ & $0.87 \pm 0.03^{\mathrm{a}}$ & $11.20 \pm 0.06^{\mathrm{a}}$ & $9.74 \pm 0.04^{\mathrm{a}}$ & $21.34 \pm 0.20^{\mathrm{b}}$ & $2.19 \pm 0.02^{\mathrm{bc}}$ \\
\hline HPHE-diet x 0.15 & $82.88 \pm 2.42^{\mathrm{a}}$ & $0.87 \pm 0.02^{\mathrm{a}}$ & $11.22 \pm 0.08^{\mathrm{a}}$ & $9.76 \pm 0.03^{\mathrm{a}}$ & $19.11 \pm 0.35^{\mathrm{c}}$ & $1.96 \pm 0.01^{\mathrm{c}}$ \\
\hline LPLE-diet x 0.0 & $73.15 \pm 4.03^{\mathrm{c}}$ & $0.80 \pm 0.04^{\mathrm{b}}$ & $9.03 \pm 0.05^{\mathrm{c}}$ & $7.22 \pm 0.02^{\mathrm{c}}$ & $23.60 \pm 0.21^{\mathrm{a}}$ & $3.27 \pm 0.02^{\mathrm{a}}$ \\
\hline LPLE-diet x 0.15 & $79.19 \pm 3.15^{b}$ & $0.83 \pm 0.03^{\mathrm{b}}$ & $10.10 \pm 0.03^{b}$ & $8.38 \pm 0.02^{b}$ & $21.14 \pm 0.31^{b}$ & $2.52 \pm 0.03^{\mathrm{b}}$ \\
\hline
\end{tabular}

Means in the same column within the same effect having different letters are significantly different at $\mathbf{P} \leq \mathbf{0 . 0 5}$.
EP = Egg production
EN = Egg number
EW = Egg weight
EM = Egg mass
FI = Feed intake
FCR $=$ Feed

conversion ratio

Fayoum J. Agric. Res. \& Dev., Vol. 31, No.2, July, 2017 


\section{REFERENCES}

A.O.A.C. (1990). Association of Official Analytical Chemists. Official Methods of Analysis 15th Ed., published by Assoc. Office. Anal. Chem., Washington, D.C., USA.

Abdel-Rahman, S.A. (1993). Effect of dietary protein level with antibiotic or probiotic supplementation on performance of laying hens. Egypt. Poult. Sci. 13 : 501-519.

Akbar M.K; J.S. Gavora; G.W. Friars and R.S. Gowe (1983). Composition of eggs by commercial size categories: Effects of genetic group, age and diet. Poult. Sci.; 62:925-933.

Andersson K. (1979). Some unconventional feedstuffs to laying hens 1. Effects on production and gross chemical composition of eggs. Swedish Journal of Agricultural; 9:29-36.

Boling, S.D.; J.L. Snow; C.M. Parsons and D.H. Baker, (2001). The effect of citric acid on calcium and phosphorus requirements of chicks fed corn soybean meal diets. Poult. Sc., 80: 783-788.

Cave, N.A.G., (1984). Effect of dietary propionic and lactic acid on feed intake by chicks. Poult. Sci., 63: 131- 134.

Chaveerach, P.; D.A. Keuzenkamp; L.J. Lipman and F.V an Knapen, (2004). Effect of organic acids in drinking water for young broilers on Campylobacter infection, volatile fatty acid production, gut microflora and histological cell changes. Poult. Sci., 83: 330-334.

Denli, M.; F. Okan and K. Celik, (2003). Effect of dietary probiotic, organic acid and antibiotic supplementation to diets on broiler performance and carcass yield. Pak. J. Nutr., 2: 89-91.

Dhawale, A., (2005). Better eggshell quality with a gut acidifier. Poult. Int., 44: $18-21$.

Dofing, J. and P. Gottschal, (1997). Microbe-microbe interactions. Pages 373389 in Gastrointestinal microbiology. Mackie, R.I. ed. Chapman and Hall. New York.

Multiple range and multiple F test. Biometrics, 11: 1-42.

Duncan, D.B. (1955). Feed Composition Tables for animal \& poultry feedstuffs used in Egypt (2001). Technical bulletin No. 1, Central Lab for Feed and Food; Ministry of Agriculture, Egypt.

Garcia E.A; A.A. Mendes; C.C. Pizzolante; E.S. Saldanha; J. Moreira; C. Mori and A.C. Pavan (2005). Protein, methionine+cystine and lysine levels for Japanese quails during the production phase. Rev. Bras. Cienc. Avic. vol.7 no.1

Garrido, M.N.; M. Skjervheim; H. Oppegaard and H. Sorum (2004). Acidified litter benefits the intestinal flora balance of broiler chickens. Appl. Environ. Microbiol., 70: 5208-5213.

Fayoum J. Agric. Res. \& Dev., Vol. 31, No.2, July, 2017 
Henry, R.F. (1974). "Clinical Chemistry Principles and Technics" 2 nd Ed., Harper and Row, Hagerstein, MD.

Jakobsen, P.E.; Kirston, S.G; K.S. Gertovey and H. Nielson (1960). Digestibility trials with poultry. 322 beretning Fraforsgs labooratoriet udgivet of statens. Husdybugsudvalg, Kobenhaven, 56:1-34.

Jensen, B.B., (1998). The impact of feed additives on the microbial ecology of the gut in young pigs. J. Anim. Feed Sci., 7: 45-64.

Kaistha, M.; S. Katoch; B.S. Katoch; M. Kumari; K.K. Dogra and C.R. Sharma (1996). Effect of dietary supplementation of useful microbes isolated from luffa cylindrical (luffa aegytiaca) and momordica charantia on the performance of broilers. Indian J. Poult. Sci., 31: 156- 162.

Lehninger, A.L., (1978). Biochemistry. Worth publishing. 509-542.

Moharrery and M. Mahzonieh (2005). Effect of malic acid on visceral characteristics and coliform counts in small intestine in the broiler and layer chickens. International Poult. Sci., 4: 761-764.

National Research Council, N.R.C. (1994). Nutrient Requirements of Poultry. 9th Revised. Ed., National Academy of Sciences Press, Washington, D.C., USA.

Patten, J.D. and P.W. Waldroup, (1988). Use of organic acids in broiler diets. Poult. Sci., 67: 1178-1182.

Roy, D.P. (2002). Influence of a propionic acid feed additive on performance of turkey poults with experimentally induced poult enteritis and mortality syndrome. North Carolina State University, Department of Poultry Science, Raleigh, 7635- 7695.

Sarra, P.G.; F. Dellaglio and V. Bottazzi, (1985). Taxonomy of lactobacilli isolated from the alimentary tract of chickens. System Appl. Microbiol., 6: 86-89 .

Shelat, S.G.; F. Arid and E. Redei, (1997). Exposure to dehydroepiandrosterone in utero affect $\mathrm{T}$ cell function in males only. Neuroimmunomodulation, 4: 154-162.

Shrivastav A.K; M.V. Raju and T.S. John (1993). Effect of varied dietary protein on certain production traits in breeding Japanese quail. Indian Journal Poultry Science 1993; 28(1):20-5.

SPSS (1993). SPSS Statistical software Package for the social sciences. 2 nd ed. HA33-N48. McGrow-Hill, Inc., USA.

Stadleman, W. J. (1977). Quality identification of shell egg in: Egg Science and Technology. 2nd Ed by W. J. Stadleman and O. J. Cotterill pub by AVI publishing company Inc. Connecticut USA.

Fayoum J. Agric. Res. \& Dev., Vol. 31, No.2, July, 2017 
RESPONSE OF JAPANESE QUAIL TO FEED BY ORGANIC

Steel, R.G.D. and J.H. Torrie (1980). Principles and procedures of statistics:

A Biometrical 2nd ed. McGraw-Hill Book Co., Inc., New York, USA.

Sturkie, P.D. (1986). "Avain Physiology". 4th ed. Springer-Verlag, New York, Inc. USA.

Thompson, J.L. and M. Hinton, (1997). Antibacterial activity of formic and propionic acids in the diet of hens on Salmonellas in the crop. Br. Poult. Sci., 1997 Mar, 38: 59-65.

Van Kol, (2005). Organic acids and essential oils in AGP free diets, P7. Antimicrobial Growth Promoters: Worldwide Ban on the Horizon. Noordwijk aan Zee, The Netherlands, Jan 31-Feb 1.

Washburn, K.W. and D.F. Nix (1974). A rapid technical for extraction of yolk cholesterol. Poult. Sci. 53: 1118-1122.

Yakout, H.M.; M.E. Omara; Y. Marie and R.A. Hassan (2004). Effect of incorporating growth promoters and different dietary protein levels into Mandarah hens layer's diets. Egypt. Poult. Sci. 24 (IV): 977994.

Zanaty , G.A.; A.S. Rady; A.M. Abou-Ashour and F.H. Abdou (2001). Productive performance of Norfa chickens as affected by dietary protein level, brooding system and season. Egypt. Poult. Sci. Vol. 21 ( I ): 237-254.

Zanaty, G.A. (2006). Optimum dietary protein and energy levels for Norfa hens during the laying period. Egypt Poult. Sci. Vol (26) (I): (207220) .

Fayoum J. Agric. Res. \& Dev., Vol. 31, No.2, July, 2017 
استجابة السمان اليابانى للتغذية بالمركبات العضوية

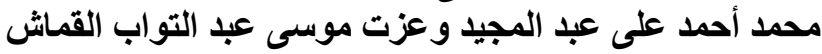

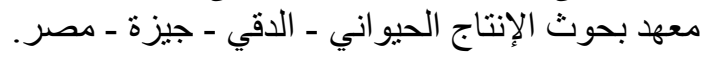

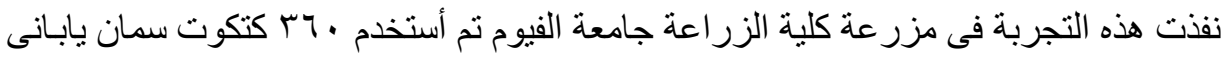

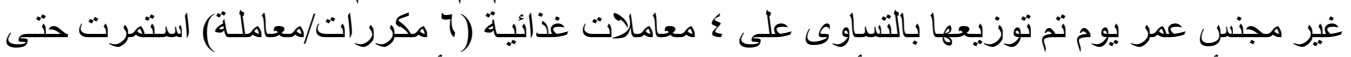

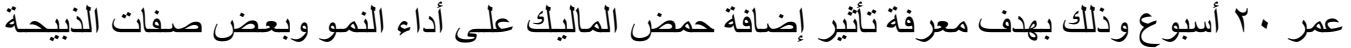

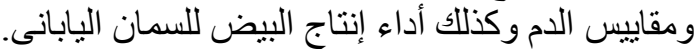

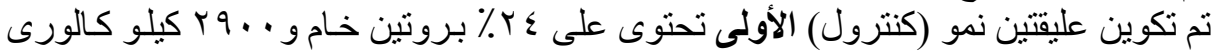

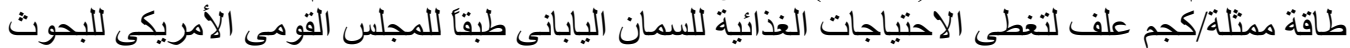

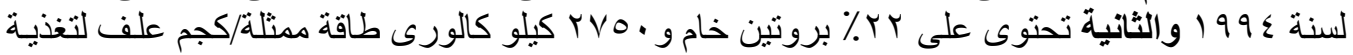

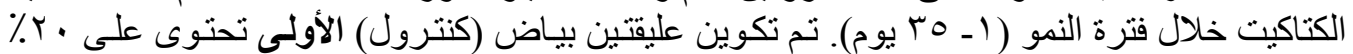

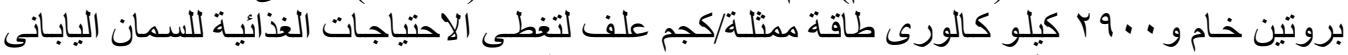

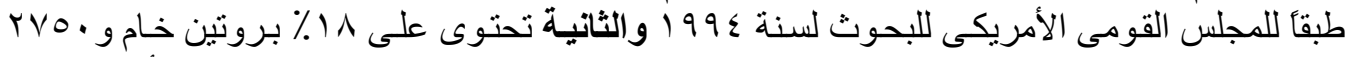

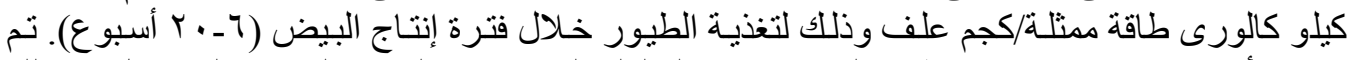

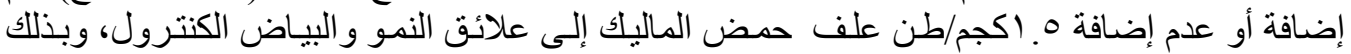

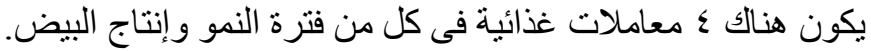

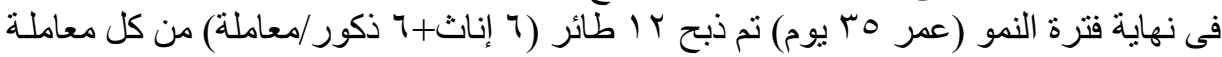

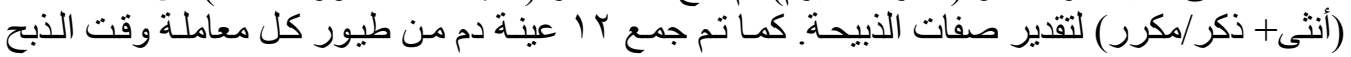

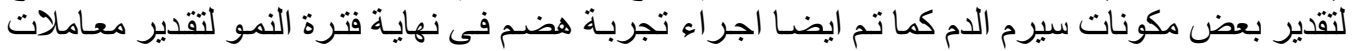

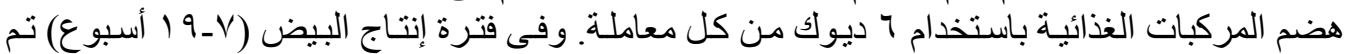

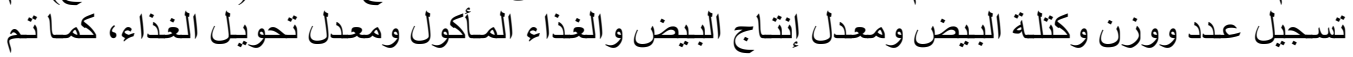

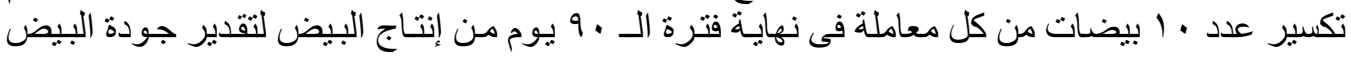

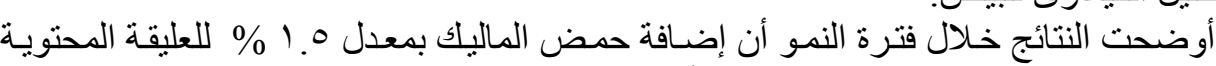

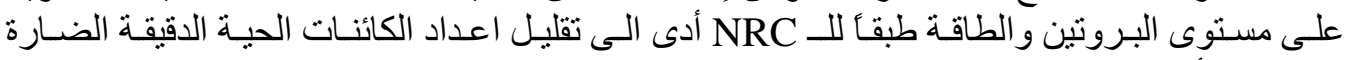

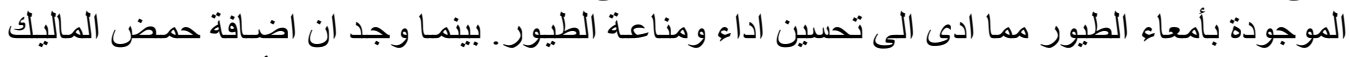

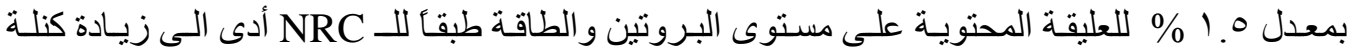

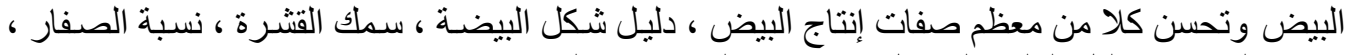
ونسبة القشرة. وتقليل العلف الماكول مما يودى الى تلى تحسين القيمة الاقتصادية.

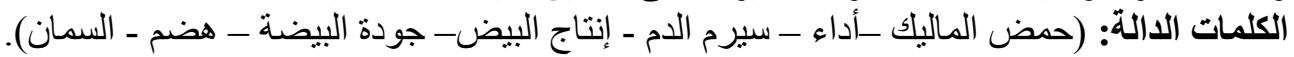

